\title{
Forest owner motivations and attitudes towards supplying biomass for energy in Europe
}

\author{
Kristina Blennow ${ }^{a, *}$, Erik Persson ${ }^{a}$, Marcus Lindner ${ }^{b}$, \\ Sónia Pacheco Faias ${ }^{c}$, Marc Hanewinkel ${ }^{d}$ \\ ${ }^{a}$ Department of Landscape Architecture, Planning and Management, Swedish University of Agricultural Sciences, \\ SE-230 53 Alnarp, Sweden \\ ${ }^{\mathrm{b}}$ European Forest Institute, Yliopistokatu 6, 80100 Joensuu, Finland \\ ${ }^{c}$ University of Lisbon, Centro de Estudos Florestais, Tapada da Ajuda, 1349-017 Lisboa, Portugal \\ ${ }^{\mathrm{d}}$ Swiss Federal Institute for Forest Snow and Landscape Research, Research Unit Forest Resources and Management, \\ $\mathrm{CH}-8903$ Birmensdorf, Switzerland
}

\section{A R T I C L E I N F O}

\section{Article history:}

Received 12 February 2014

Received in revised form

3 May 2014

Accepted 5 May 2014

Available online 28 May 2014

\section{Keywords:}

Land-use change

Forest management

Bioenergy

Biomass

Stemwood

Private forest owner

\begin{abstract}
A B S T R A C T
The European Commission expects the use of biomass for energy in the EU to increase significantly between 2010 and 2020 to meet a legally binding target to cover at least $20 \%$ of EU's total energy use from renewable sources in 2020. According to estimates made by the member states of the EU, the direct supply of biomass from forests is expected to increase by $45 \%$ on a volume basis between 2006 and 2020 in response to increasing demand (Beurskens LWM, Hekkenberg M, Vethman P. Renewable energy projections as published in the national renewable energy action plans of the European Member states. ECN and EEA; 2011. http://https://www.ecn.nl/docs/library/report/2010/e10069.pdf [accessed 25.04.2014]; Dees M, Yousef A, Ermert J. Analysis of the quantitative tables of the national renewable energy action plans prepared by the 27 European Union Member States in 2010. BEE working paper D7.2. Biomass Energy Europe project. FELIS - Department of Remote Sensing and landscape information Systems, University of Freiburg, Germany; 2011). Our aims were to test the hypotheses that European private forest owners' attitudes towards supplying woody biomass for energy (1) can be explained by their responses to changes in prices and markets and (2) are positive so that the forest biomass share of the EU 2020 renewable energy target can be met. Based on survey data collected in 2010 from 800 private forest owners in Sweden, Germany and Portugal our results show that the respondents' attitudes towards supplying woody biomass for energy cannot be explained as direct responses to changes in prices and markets. Our results, furthermore, imply that European private forest owners cannot be expected to supply the requested amounts of woody biomass for energy to meet the forest biomass share of the EU 2020 renewable energy target, at least if stemwood is to play the important role as studies by Verkerk PJ, Anttila P, Eggers J, Lindner M, Asikainen A. The realisable potential supply of woody biomass from forests in the European Union. For Ecol Manag 2011;261: 2007-2015, UNECE and FAO. The European forest sector outlook study II
\end{abstract}

* Corresponding author. Tel.: +4640415230.

E-mail addresses: kristina.blennow@slu.se (K. Blennow), erik.persson@slu.se (E. Persson), marcus.lindner@efi.int (M. Lindner), soniapf@isa.utl.pt (S.P. Faias), marc.hanewinkel@wsl.ch (M. Hanewinkel). http://dx.doi.org/10.1016/j.biombioe.2014.05.002

0961-9534/@ 2014 Elsevier Ltd. All rights reserved. 
2010-2030. United Nations, New York and Geneva; 2011 [abbreviated to EFSOS II] and Elbersen B, Staritsky I, Hengeveld G, Schelhaas MJ, Naeff H, Böttcher H. Atlas of EU biomass potentials; 2012. Available from: http://www.biomassfutures.eu [accessed 14.10.2013] suggest.

() 2014 Elsevier Ltd. All rights reserved.

\section{Introduction}

The European Commission expects the use of biomass for energy in the EU to increase significantly between 2010 and 2020 to meet a legally binding target to cover at least $20 \%$ of EU's total energy use from renewable sources in 2020 [1]. According to National Renewable Energy Action Plans (NREAP) reporting estimates made by the member states of the $\mathrm{EU}$, today woody biomass is the most important source of renewable biomass [2-4]. Its use is expected to increase by $45 \%$ by volume between 2006 and 2020, corresponding to $8 \%$ of the expected total increase in renewable energy use in the EU $[3,4]$. In the NREAPs this direct supply of woody biomass from forestry for energy use is estimated in total from fellings, residues from fellings and landscape management and only few countries have reported the amount of feedstock in further detail [2].

Several studies have, however, estimated the future potential woody biomass supply from European forests also for different compartments. The most comprehensive study was carried out in the EUwood project $[5,6]$ and the results have been used in follow-up work in the context of the European Forest Sector Outlook study EFSOS II [7]. The same results have also been used in the Biomass Future project [8].

According to EFSOS II [7], an ambitious bioenergy policy could mobilize $55 \%$ more energy wood by 2020 , whereby the total wood use for energy would increase from 435 to $673 \mathrm{Mm}^{3}$ per year. The additional extraction of $238 \mathrm{Mm}^{3}$ woody biomass per year for energy could only be achieved by mobilizing a number of different biomass compartments. Besides a large contribution from harvest residues and stumps, also the extraction of stemwood would increase by $50.8 \mathrm{Mm}^{3}$ from 2010 to 2020. This is a substantial amount, considering that the 2010 level of roundwood removals from EU 27 forests was $418.7 \mathrm{Mm}^{3}$ [9]. However, as also the reference scenario of EFSOS II projected increased stemwood removals, the net effect of the $202020 \%$ renewable energy target was an additional 18.3 $\mathrm{Mm}^{3}$ year $^{-1}$ of stemwood removals for energy generation by 2020 . Another modeling study with slightly different scenario assumptions estimated $40.8 \mathrm{Mm}^{3}$ year ${ }^{-1}$ additional stemwood removals for energy generation as a net effect of the 2020 renewable energy policy targets [10]. The larger share in the latter study was caused by considerable replacement of wood for material use, which was diverted to energy use (whereas in the EFSOS II scenario wood supply for material use increased as well).

In the study by Verkerk et al. [6] and in the subsequent work $[7,10]$ prices for wood, forest products, and energy are assumed to show steady long-term growth and thereby act as a basic incentive for forest owners to increase the supply by intensifying forest management and expanding the land used for forestry. Because rotation periods of European forests are typically several decades long [11] contributing more stemwood for energy implies that the management objective of some forest stands that today are managed for stemwood for timber, pulp and material use would have to be changed to woody biomass (in any form) for energy before the end of the rotation period. Lacking empirical evidence of the motivations and attitudes of European forest owners to increase the supply of woody biomass for energy, Verkerk et al. [6] and UNECE and FAO [7] assumed that the availability of wood from privately owned holdings was lower on the very smallest private holdings and increasing rapidly when the holding size increased. The assumption is based on a positive correlation between management intensity of U.S. private forest owners and size of their holdings. This is explained to result from better financial situations of owners of large holdings [12]. The effect is implemented by multiplying the maximum harvest level with a factor derived from the size of the holding. The future change in forest area is expected to follow the observed trend of increasing forest area for the period 1990-2005 for all countries of the EU, except Finland where the trend is in the opposite direction [13].

Fifty percent of the forest land in Europe is privately owned $[7,14,15]$. Hence, private forest owners' use of the land and the way they manage their forests will strongly influence the future supply of woody biomass for energy in Europe. The aims of the present study were to test the hypotheses that European private forest owners' attitudes towards supplying woody biomass for energy

1. can be explained by their responses to changes in prices and markets.

2. are positive so that the forest biomass share of EU 2020 renewable energy target can be met.

Empirical consequences of the hypotheses are that forest owners are willing to change their current forest management objective and their land-use to supply more woody biomass for energy if it can be made at profit, and that they have positive attitudes towards meeting the expected supply of woody biomass for energy. The study was based on survey data collected in 2010 from 800 private forest owners in Sweden, Germany and Portugal.

\section{Materials and methods}

A questionnaire study was designed to assess land owner motivations and attitudes towards supplying more biomass for energy across the EU. The questionnaire was distributed 
Table 1 - Questions and response options.

Question

1. Do you believe that the strong demand for woody biomass for energy generation will be persistent over the coming 10 years?

2. Assume that you have during several years invested time and money to keep the forest on your property well managed for stemwood production. Assume furthermore that you can improve the financial return by converting to production of woody biomass for energy generation. Is it more likely that you would continue to manage the forest for stemwood production, or that you would convert to production of woody biomass for energy generation?

3. Would you, if given the opportunity, be willing to convert ... to meet the demand for woody biomass for energy generation?

a. Pasture land to forest.

b. Land used for agriculture to forest.

c. Land used for other purposes than pasture and agriculture to forest.

d. Forest land to land for cultivation of energy crops.

4. What size of area is used for different land-uses on your management unit?

Response options

Yes, definitely

Yes, probably

Do not know

Probably not

Definitely not

Mark with one cross on the scale from "Most likely that I would continue manage the forest stands for stemwood production" (0) to "Most likely I would convert to production of woody biomass for energy generation" (100).

\author{
Yes, definitely \\ Yes, probably \\ Probably not \\ Definitely not \\ Do not know \\ Forest land ha \\ Pasture land ha \\ Agricultural land ha \\ Land for other uses ha
}

\footnotetext{
a Scale was reclassified according to 0-20. Most likely that I would continue manage the forest stands for stemwood production; 21-40, likely that I would continue manage the forest stands for stemwood production; 41-59, do not know; 60-79, likely I would convert to production of woody biomass for energy generation; 80-100, most likely I would convert to production of woody biomass for energy generation.

b The "do not know" answer should not be seen as the mid-point on the scale because it is an epistemic statement while the other alternative answers to the question are value statements. It is interpreted as meaning do not know or indifferent.
}

among 1588 private forest owners owning forest in Sweden (Kronoberg County), Germany (Black Forest) and Portugal (Chamusca County). The countries were chosen to cover land owners operating in a wide range of bio-climatic conditions as well as economic-social-political structures. The questions asked about their personal beliefs in a persistent and strong demand for woody biomass for energy, their attitudes towards changing their forest management objective from stemwood to woody biomass for energy use at profit and to convert land used for grazing, agriculture and other purposes into forest land to supply woody biomass for energy as well as to convert forest into land for energy crop production (Table 1). The questionnaire was formulated in English and translated to the native language of the respondents in each respective country. The Swedish forest owners were randomly sampled from contact persons with forest holdings larger than 5 ha listed in the Swedish Real Property Register (Swedish Act 2000:224). In Germany and Portugal, the questionnaire was sent to all members of the forest owner organizations Forstkammer Baden-Württemberg and ACHAR - Associação dos agricultores de Charneca (in Chamusca), respectively. The questionnaires were distributed by mail during spring, 2010. A total of 871 forest owners returned the questionnaire $(54.8 \%)$ of which 800 responded to all the questions used is this study. Details of the data collection procedure and quality control are described in Ref. [16]. The factor used by Verkerk et al. [6] and UNECE and FAO [7] to account for lower supply of woody biomass from privately owned forests was used on the holdings owned by the respondents to the questionnaire (Tables 2 and 3) and was calculated as $50 \%$ in forest holdings $<1$ ha, increasing to $85 \%$ in forest holdings $\geq 5$ ha and to $96 \%$ in forest holdings $\geq 80$ ha [6]. The significance of differences in mean ranks of response options describing the strength of beliefs (e.g. Ref. [17]) and attitudes between groups of respondents were tested at $\alpha=0.05$ using the non-parametric Wilcoxon rank sum test with continuity correction. Tests involving responses to the question 3 (Table 1) were made excluding "Indifferent and Do not know" responses. All analyses were conducted using the $\mathrm{R}$ Project for Statistical Computing package v3.0.2 [18].

\section{Results}

Altogether, $93.5 \%$ (S.E. $\pm 0.9 \%$ ) of the respondents owning $92 \%$ of the forest area (Table 2) reported weak or strong belief (response options "Yes, probably" and "Yes, definitely", respectively, to Question 1 in Table 1) that the strong demand for woody biomass for energy will persist over the coming ten years (Fig. 1). The belief in a persistent and strong demand for woody biomass was significantly stronger among respondents

Table 2 - Size of areas used for different purposes and owned by respondents in each country (see Table 1, Question 4).

\begin{tabular}{lccc} 
Land-use class & Sweden (ha) & Germany (ha) & Portugal (ha) \\
\hline Forest & 25,800 & 27,582 & 23,662 \\
Pasture & 1,895 & 4,097 & 3,541 \\
Agriculture & 2,408 & 2,454 & 1,730 \\
Other & 2,474 & 392 & 558 \\
Total & 32,577 & 34,525 & 29,491 \\
\hline
\end{tabular}


Table 3 - Harvest level factor used by Verkerk et al. [4] and UNECE and FAO [5] reflecting the private forest owners' opportunities to exploit a higher demand for woody biomass by intensified forest management.

\begin{tabular}{lcccc} 
& $\begin{array}{c}\text { Sweden } \\
(\%)\end{array}$ & $\begin{array}{c}\text { Germany } \\
(\%)\end{array}$ & $\begin{array}{c}\text { Portugal } \\
(\%)\end{array}$ & $\begin{array}{c}\text { Total } \\
(\%)\end{array}$ \\
\hline $\begin{array}{l}\text { Harvest level } \\
\text { reduction factor }\end{array}$ & 94.3 & 93.9 & 95.9 & 94.6 \\
\hline & & & \\
\hline & The size of holding was represented as the forest area per holding \\
owned by the respondents in the present study.
\end{tabular}

in Germany than among respondents in Sweden $(\mathrm{W}=54685.5$, $p$-value $=1.68 \mathrm{e}-4)$ and Portugal $(\mathrm{W}=4899, p$-value $<2.2 \mathrm{e}-16)$, and significantly stronger in Sweden than in Portugal $(\mathrm{W}=15473, p$-value $=8.51 \mathrm{e}-13)$ (Table 4$)$.

Nevertheless, only $10 \%$ (S.E. $\pm 1 \%$ ) of the respondents owning $12 \%$ of the forest area (Table 2 ) reported a weakly positive or strongly positive attitude (response options "Likely that I would convert to production of woody biomass for energy generation" and "Most likely that I would convert to production of woody biomass for energy generation", respectively, to question 2 in Table 1) to convert to producing woody biomass for energy use in forest stands currently managed for stemwood production, even if it would lead to higher financial return (Fig. 2). The attitude was most positive among respondents in Portugal (43\%, S.E. $\pm 6 \%$ ), intermediate among respondents in Sweden (8\%, S.E. $\pm 2 \%$ ), and the least positive among respondents in Germany (6\%, S.E. $\pm 1 \%$ ). The attitudes towards changing the forest management objective from stemwood to woody biomass was significantly more positive among respondents in Portugal than among respondents in Sweden $(\mathrm{W}=15473, p$-value $=8.51 \mathrm{e}-13)$ and Germany ( $\mathrm{W}=4899, p$-value $<2.2 \mathrm{e}-16$ ) and significantly more positive in Sweden than in Germany ( $\mathrm{W}=15810.5, p$ -

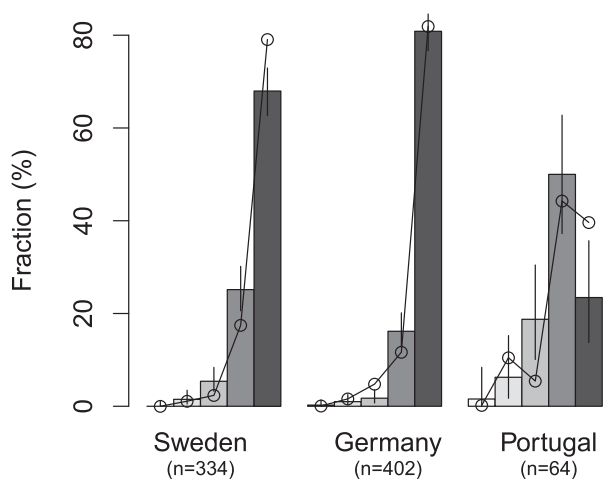

Fig. 1 - Respondents'strength of belief in a strong and persistent demand for woody biomass, per country. Responses to question 1 (Table 1). The increasing shades of grey code for responses from "definitely not" over "probably not", “do not know", "yes, probably", to "yes, definitely", so that darker shades exhibit the strongest degree of belief in a strong and persistent demand for woody biomass, respectively. Bars denote $95 \%$ confidence intervals per country. The circles represent the fraction (\%) of land per class and country.
Table 4 - Fraction of respondents strongly believing in a persistent and strong demand for woody biomass over the coming 10 years by country and the fraction of forest land area owned by these respondents.

\begin{tabular}{lcc} 
& $\begin{array}{c}\text { Strong belief in a persistent and } \\
\text { strong demand for woody } \\
\text { biomass }^{\text {a }}(\%) \text { (S.E.) }\end{array}$ & $\begin{array}{c}\text { Forest land } \\
\text { area } \\
\text { owned }^{\mathrm{b}}(\%)\end{array}$ \\
\hline Sweden & $93( \pm 1)$ & 97 \\
Germany & $97.0( \pm 0.8)$ & 94 \\
Portugal & $73( \pm 6)$ & 84 \\
& $93.5( \pm 0.9)$ & 92 \\
Total & & \\
\hline a Response option "yes, certainly" to Question 1 in Table 1. \\
b Calculated from responses to Question 4 in Table 1. \\
\hline
\end{tabular}

value $=2.29 \mathrm{e}-12$ ). Taken together, $63 \%$ (s.e. $\pm 2 \%$ ) of the respondents owning $55 \%$ of the forest land reported a strongly negative attitude towards changing the forest management objective from stemwood to biomass for energy in stands currently managed for stemwood (response option "Most likely that I would continue manage the forest stands for stemwood production" to question 2 in Table 1) (Fig. 2).

The respondents' attitudes towards changing land use differed between land-use classes (Fig. 3) (Table 5). Altogether $51 \%$ (S.E. $\pm 2 \%$ ) of the respondents owning $66 \%$ of the total pasture land (Table 2) reported a weakly positive or strongly positive attitude towards converting to produce woody biomass on all or part of this land (response options "Yes, probably" and "Yes, definitely", respectively, to Question 3 in Table 1) (Fig. 3). The attitudes towards changing land-use from pasture to forest were significantly more positive among respondents in Germany than in Sweden ( $W=36328.5, p$ value $=6.28 \mathrm{e}-3$ ). The fraction of respondents reporting a weakly positive or strongly positive attitude towards converting agriculture land to forest land was only $27 \%$ (S.E. $\pm 2 \%$ ) owning $43 \%$ of the agricultural land (Fig. 3) (Table 2). Among respondents owning land used for other purposes than forest, grazing or agriculture, $57 \%$ (S.E. $\pm 2 \%$ ) owning $71 \%$ of the land reported a weakly positive or strongly positive attitude towards converting to producing forest biomass for energy use on this land (Fig. 3), while only $25 \%$ (S.E. $\pm 2 \%$ ) of respondents owning $31 \%$ of the forest area reported a weakly positive or strongly positive attitude towards converting to producing energy crop on forest land (Fig. 3). Conversion of forest to production of energy crop was significantly more positive among respondents in Portugal than among respondents in Sweden ( $\mathrm{W}=10101, p$-value $=3.77 \mathrm{e}-06)$ and Germany $(\mathrm{W}=5037, p$-value $=6.50 \mathrm{e}-08)$, and more positive among respondents in Sweden than in Germany ( $W=44430, p$ value $=2.62 \mathrm{e}-3$ )

\section{Discussion}

The results show that even if the individual forest owner can change the management objective from stemwood to woody biomass for energy at a profit, only very few held a positive attitude towards making the change (Figs. 1 and 2). Hence, European private forest owners' attitudes towards supplying 


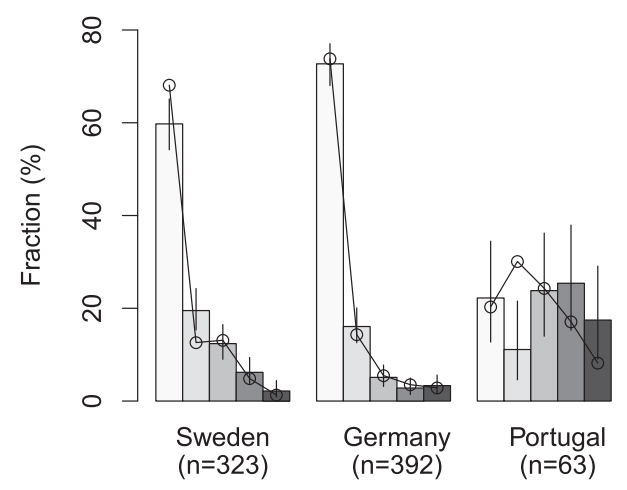

Fig. 2 - Respondents' attitudes towards changing the forest management objective from stemwood to woody biomass for energy at profit, per country. Responses to Question 2 (Table 1). The increasing shades of grey code for classified responses on a scale spanning 0-100 from "Most likely continue managing the forest for production of stemwood" ( $\leq 20)$ to "Most likely change the management objective to production of woody biomass for energy" $(\geq 80)$, so that darker shades exhibit the most positive attitude to change management objective to woody biomass for energy in stands currently managed for stemwood. Bars denote $95 \%$ confidence intervals per country. The circles represent the fraction (\%) of land per class and country.

woody biomass for energy cannot be explained as direct responses to changes in prices and markets (Figs. 2 and 3). Furthermore, if stemwood is expected to play an important role to meet the EU 2020 renewable energy target, as suggested by Verkerk et al. [6], UNECE and FAO [7] and Böttcher et al. [10], our results show that European private forest owners cannot be expected to supply the requested amounts of woody biomass for energy.

Although the respondents in our study generally asserted strong belief in a persistent and strong demand for woody biomass for energy use (Fig. 1) their readiness to change the management objective to woody biomass for energy in forest stands currently managed for stemwood was low, even if it would lead to higher financial return (Fig. 2). Only one respondent in ten, representing $12 \%$ of the forest area, reported a weakly positive or strongly positive attitude to convert to producing woody biomass for energy at a profit in forest stands currently managed for stemwood. Almost two respondents out of three held a strongly negative attitude towards making the change (Fig. 2). Assuming that respondents with a weakly positive and strongly positive attitude towards making the change from stemwood to biomass for energy will indeed make the change and that the respondents represent the European private forest owners in general, only $12 \%$ of the privately owned forest land will be available for providing stemwood for energy generation. Hence, a conservative estimate of the harvest level of stemwood for energy in privately owned forests in Europe is $12 \%$ of the maximum.

Our results are in agreement with those of Wilnhammer et al. [19] who found that that the supply of woody biomass for energy from privately owned forests in southern Germany is substantially lower than the technical potential. They, furthermore, found the supply of biomass for energy related to self-consumption among owners of small holdings. Recent studies of the attitude among U.S. private forest owners to supply woody biomass for energy indicate that the realizable potential supply varies between states and is in some states substantially lower than the technical potential (see Refs. [20-25]). By way of example, Aguilar et al. [25] found that one third of Missouri non-industrial private forest owners responding to a questionnaire indicated no willingness to harvest woody biomass for energy irrespective of price.

The harvest levels of biomass for any use in privately owned forests in the reference scenarios by Verkerk et al. [6] and UNECE and FAO [7] amounted to $94.6 \%$ of the maximum, when calculated for the forest owners responding to the questionnaire (Table 3). The fraction used in the high biomass scenarios was $5 \%$ higher. The rather small reduction of the maximum harvest levels resulting from the high biomass scenarios as well as from the reference scenarios appear highly unrealistic when compared to the harvest levels reduced to $12 \%$ of the maximum estimated for supplying stemwood for energy in this study. Part of the difference might be attributed to different interpretations of the term stemwood. While Verkerk et al. [6] and UNECE and FAO [7] refer to stemwood as stems of all diameters some of the respondents might have referred to stems of large diameters only. Nevertheless, the high biomass scenarios as well as the reference scenarios, the latter quantifying the supply needed to meet the EU 2020 renewable energy target, appears unrealistic, at least for supplying stemwood for energy from privately owned forests in Europe.

In general, the attitude appears more positive for changing land-use than for changing forest management objective from stemwood to woody biomass (Figs. 2 and 3). The attitude to change the forested area and thereby contribute to the supply of biomass differed between land-uses (Fig. 3). Among respondents in Sweden and Germany, the attitude was most positive for converting land used for other purposes than agriculture and pasture into forest (Fig. 3) (Table 5). While the land area available to the German respondents for this landuse class is substantially lower than for agriculture and pasture, in Sweden land used for other purposes (e.g. low producing bogs and mires) make up $13 \%$ of the land area available to the respondents (Table 2). Because of the long time it takes before a new forest can supply significant amounts of woody biomass [11], increasing the land area for supplying woody biomass for energy only plays a smaller role for the near future until 2020, especially if land of low productivity is to be used. A shorter rotation period for energy crops implies that conversion of forest to energy crops would provide earlier access to harvestable biomass. However, among respondents in Germany and Sweden the attitude towards converting forest to energy crop was less positive than towards expanding the forest (Table 5). The attitude towards converting forest to energy crop was most positive among respondents in Portugal (Fig. 3).

Also other differences in attitudes between respondents from the three countries can be noted. Although the belief in a persistent and strong demand for woody biomass for energy was least strong among respondents in Portugal (Fig. 1), the 

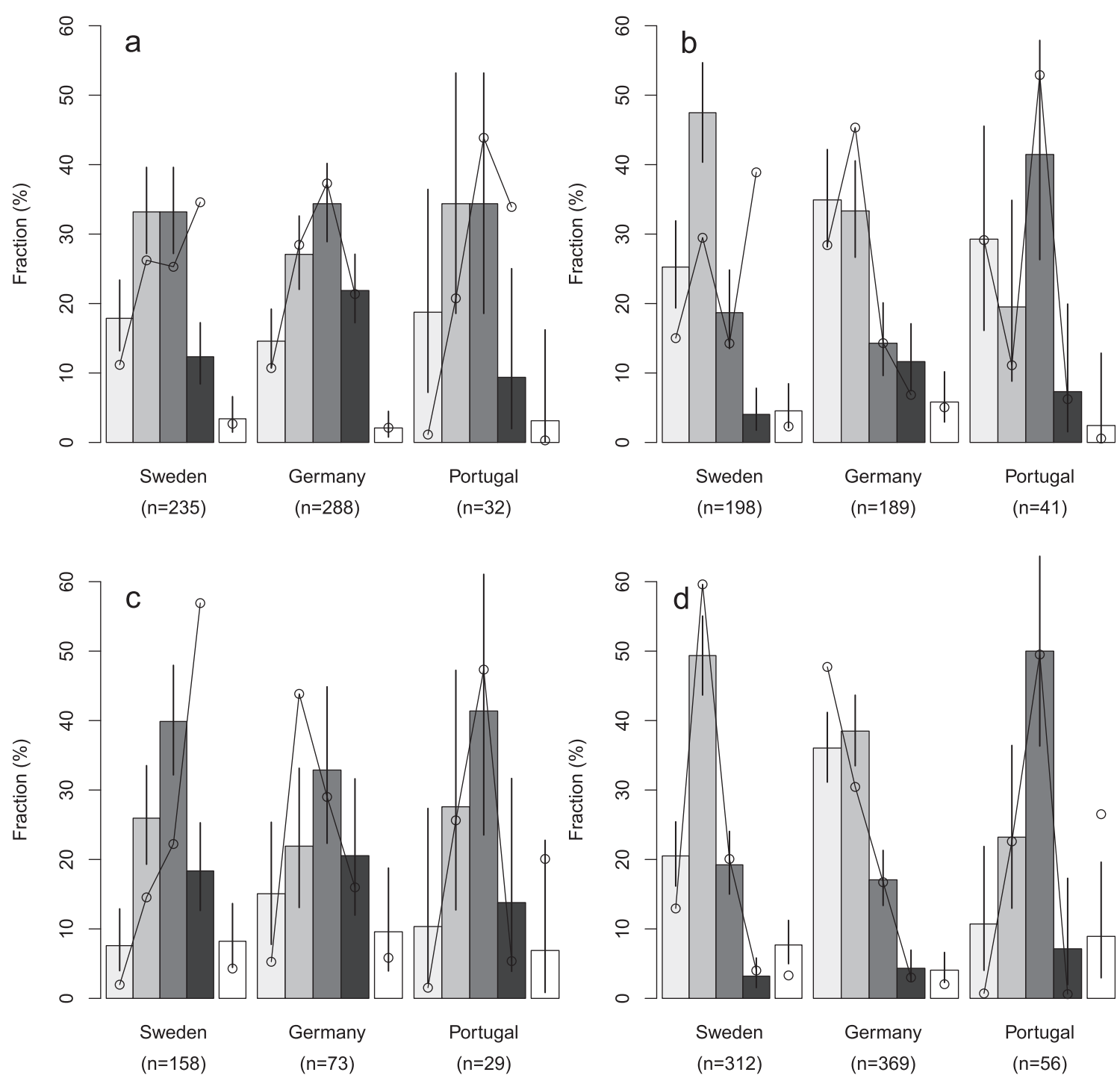

Fig. 3 - Respondents' attitudes towards changing land-use, per country. Responses to question 3 (Table 1). Land-use change from pasture to forest (a), agriculture to forest (b), other uses than pasture, agriculture and forest to forest (c), and forest to land for energy crop production (d), per country. The increasing shades of grey code for responses from "definitely not" over "no, probably not", "yes, probably", to "yes, definitely", so that darker shades exhibit the most positive attitude towards making the change, respectively. White codes for "indifferent and do not know" and is placed at the side and not in the center as in Figs. 1 and 2. Bars denote $95 \%$ confidence intervals per country. The circles represent the fraction (\%) of land per class and country.

attitudes to take measures to respond to the increasing demand for woody biomass was most positive among Portuguese respondents (Figs. 2, 3). Responses from more land owners would have been needed to paint a clearer picture of the situation in Portugal. Nevertheless, the total land area owned by the respondents in each country, respectively, was of comparable sizes (Table 2). The results of the present study stand in contrast to predictions made using a structural model (e.g. Ref. [26]) whereby the capacity to adapt to effects of climate change are seen as mainly influenced by structures in the society, including financial wealth. In contrast to the empirical results for the Portuguese respondents in the present study (Figs. 1-3) and to the results of Blennow et al. [27], the structural model predicts lower capacity to adapt to effects of climate change in southern Europe than in northern Europe $[28,29]$.

However, evidence from several sources show that the way private forest owners use and manage their land is influenced by more than economic factors (see Ref. [17]). For example, studies have demonstrated that European private forest owners often are motivated to own a forest for a multitude of reasons (e.g. Refs. [15,30-33]). Because significant environmental, recreational, and financial effects can be expected from taking measures to increase the supply of woody biomass [6,7], changing management objective or land-use would result in personal value conflicts. Prioritisation between these values in combination with the beliefs the respondents have about how to reach the goals likely explain 
Table $\mathbf{5}$ - Statistically significant differences in attitudes towards changing land use between respondents in each country, respectively.

\begin{tabular}{ll} 
Sweden & \multicolumn{1}{c}{ Germany } \\
\hline $\mathrm{OF}>\mathrm{PF}$ & $\mathrm{OF}>\mathrm{AF}$ \\
$\mathrm{W}=19752.5, p$-value $=6.22 \mathrm{e}-4$ & $\mathrm{~W}=7848, p$-value $=2.71 \mathrm{e}-05$ \\
$\mathrm{OF}>\mathrm{AF}$ & $\mathrm{OF}>\mathrm{FE}$ \\
$\mathrm{W}=19879.5, p$-value $=9.62 \mathrm{e}-14 \mathrm{~W}=16541.5, p$-value $=1.46 \mathrm{e}-08$ \\
$\mathrm{OF}>\mathrm{FE}$ & $\mathrm{PF}>\mathrm{AF}$ \\
$\mathrm{W}=29996, p$-value $=2.60 \mathrm{e}-15$ & $\mathrm{~W}=16576.5, p$-value $=2.04 \mathrm{e}-10$ \\
$\mathrm{PF}>\mathrm{AF}$ & $\mathrm{PF}>\mathrm{FE}$ \\
$\mathrm{W}=16247, p$-value $=6.77 \mathrm{e}-06$ & $\mathrm{~W}=28981.5, p$-value $<2.2 \mathrm{e}-16$ \\
$\mathrm{PF}>\mathrm{FE}$ & \\
$\mathrm{W}=25483, p$-value $=4.65 \mathrm{e}-06$ & \\
\hline
\end{tabular}

Pasture to forest (PF), agriculture to forest (AF), other land uses than pasture and agriculture to forest (OF), and forest to energy crop (FE), more positive $(>)$, and less positive $(<)$.

the attitudes private forest owners have towards changing their forest management and land-use to provide more woody biomass for energy observed in this study. Hence, it cannot be assumed that forest owners respond to market and pricing mechanisms irrespective of for what purpose the forest product is to be used. As a consequence, European private forest owners cannot be expected to supply the increasing demand for woody biomass for energy to meet the legally binding EU 2020 renewable energy target.

\section{Conclusions}

Our study provides the first empirical evidence that European private forest owners' readiness to increase the supply of woody biomass for energy is substantially lower than assumed in studies by Verkerk et al. [6], UNECE and FAO [7], and Elbersen et al. [8], at least with respect to stemwood for energy. The readiness, furthermore, remained unexplained by changes in prices and market. Because stemwood for energy makes up a substantial part of the expected supply of woody biomass for energy, the future supply of woody biomass for energy from privately owned forests in Europe is overestimated in these studies. We conclude that the low readiness to change management objective to woody biomass for energy and to provide more land for biomass supply among private forest owners from three countries in a latitudinal gradient over Europe have strong implications for meeting the forest biomass share of the legally binding 2020 target for renewable energy in the European Union.

\section{Acknowledgements}

The study was supported by the EU project MOTIVE ("Models for adaptive forest management", grant 226544) to K.B., E.P, M.L., S.P.F. and M.H. and the foundation for strategic environmental research programme Mistra-SWECIA to K.B. The authors also wish to thank the respondents and the Swedish Forest Agency, Forstkammer Baden-Württemberg and ACHAR - Associação dos agricultores de Charneca for sampling and supplying us with addresses of the forest owners, J. Norman, S. Goetz and M. Tomé for assistance with the survey, and $\mathrm{H}$. Verkerk for helpfully providing background information.

\section{R E F E R E N C E S}

[1] RED Directive 2009/28/EC of the European Parliament and of the Council of 23 April 2009 on the promotion of the use of energy from renewable sources and amending and subsequently repealing Directives 2001/77/EC and 2003/30/ EC. 2009/28. Brussels: E. Union; 2009.

[2] Roadmaps of how each Member State of the European Union expects to reach its legally binding 2020 target for the share of renewable energy in their final energy consumption. NREAP National Renewable Energy Action Plans; 2010 [accessed 22.04.2014], http://ec.europa.eu/energy/ renewables/action_plan_en.htm.

[3] Beurskens LWM, Hekkenberg M, Vethman P. Renewable energy projections as published in the national renewable energy action plans of the European Member states. ECN and EEA; 2011 [accessed 25.04.2014], https://www.ecn.nl/docs/ library/report/2010/e10069.pdf.

[4] Dees M, Yousef A, Ermert J. Analysis of the quantitative tables of the national renewable energy action plans prepared by the 27 European Union Member States in 2010 BEE working paper D7.2. Biomass Energy Europe project. Germany: FELIS - Department of Remote Sensing and landscape information Systems, University of Freiburg; 2011.

[5] Mantau U, Saal U, Prins K, Steierer F, Lindner M, Verkerk H, et al. EU wood - real potential for changes in growth and use of EU forests; 2010. p. 160. Available from: http://ec.europa. eu/energy/renewables/studies/doc/bioenergy/euwood_final_ report.pdf [retrieved 14.10.2013].

[6] Verkerk PJ, Anttila P, Eggers J, Lindner M, Asikainen A. The realisable potential supply of woody biomass from forests in the European Union. For Ecol Manag 2011;261:2007-15.

[7] UNECE and FAO. The European forest sector outlook study II 2010-2030. New York and Geneva: United Nations; 2011 [abbreviated to EFSOS II].

[8] Elbersen B, Staritsky I, Hengeveld G, Schelhaas MJ, Naeff H, Böttcher H. Atlas of EU biomass potentials; 2012. Available from: www.biomassfutures.eu [accessed 14.10.2013].

[9] State of Europe's forests 2011. Status and trends in sustainable forest management in Europe. Forest Europe, UNECE and FAO; 2011 [accessed 14.10.2013], www.unece.org.

[10] Böttcher H, Verkerk PJ, Gusti M, Havlik P, Grassi G. Projection of the future $\mathrm{EU}$ forest $\mathrm{CO}_{2}$ sink as affected by recent bioenergy policies using two advanced forest management models. GCB Bioenergy 2012;4:773-83.

[11] Kaipainen T, Liski J, Pussinen A, Karjalainen T. Managing carbon sinks by changing rotation length in European forests. Environ Sci Policy 2004;7:205-19.

[12] Straka T, Wisdom H, Moak J. Size of forest holding and investment behaviour of non-industrial private owners. J For 1984;82:495-6.

[13] State of Europe's forests 2007. The MCPFE report on sustainable forest management in Europe. MCPFE; 2007 [retrieved 14.10.2013], www.foresteurope.org.

[14] Pulla P, Schuck A, Verkerk PJ, Lasserre B, Marchetti M, Green T. Mapping the distribution of forest ownership in Europe. EFI technical report; 2013. p. 91.

[15] Schmithusen F, Hirsch F. Private forest ownership in Europe. Geneva timber and forest discussion papers 49. ECE/TIM/DP/ 49/SP/25. Geneva: UNECE/FAO Forestry and Timber Section; 2010. 
[16] Persson E, Norman J, Götz S, Faias SP, Hanewinkel M, Tomé $\mathrm{M}$ et al. A report on stakeholder approaches to and views on ways and options for handling uncertainty and change; 2011. Available from: www.motive-project.net/ [accessed 08.10.2013].

[17] Blennow K, Persson J, Wallin A, Vareman N, Persson E. Understanding risk in forest ecosystem services: implications for effective risk management, communication and planning. Forestry 2014;87:219-28. http://dx.doi.org/ 10.1093/forestry/cpt032.

[18] R Development Core Team. R: a language and environment for statistical computing. Vienna, Austria: R Foundation for Statistical Computing; 2013 [accessed 15.01.2014], www.Rproject.org.

[19] Wilnhammer M, Rothe A, Weis W, Wittkopf S. Estimating forest biomass supply from private forest owners: a case study from Southern Germany. Biomass Bioenerg 2012;47:177-87.

[20] Joshi O, Mehmood SR. Factors affecting nonindustrial private forest landowners' willingness to supply woody biomass for bioenergy. Biomass Bioenerg 2011;35:186-92.

[21] Joshi O, Grebner DL, Munn IA, Hussain A, Gruchy SR. Understanding landowner preferences for woody biomass harvesting: a choice experiment-based approach. For Sci 2013;59:549-58.

[22] Paula AL, Bailey C, Barlow RJ, Morse W. Landowner willingness to supply timber for biofuel: results of an Alabama survey of family forest landowners. South J Appl 2011;35:93-7.

[23] Markowski-Lindsay M, Stevens T, Kittredge DB, Butler BJ, Catanzaro P, Damery D. Family forest owner preferences for biomass harvesting in Massachusetts. For Policy Econ 2012;14:127-35.
[24] Leitch ZJ, Lhotka JM, Stainback GA, Stringer JW. Private landowner intent to supply woody feedstock for bioenergy production. Biomass Bioenerg 2013;56:127-36.

[25] Aguilar FX, Daniel M, Narine LL. Opportunities and challenges to the supply of woody biomass for energy from Missouri nonindustrial privately owned forestlands. J For 2013;111:249-60.

[26] Smit B, Wandel J. Adaptation, adaptive capacity, and vulnerability. Global Environ Chang 2006;16:282-92.

[27] Blennow K, Persson J, Tomé M, Hanewinkel M. Climate change: believing and seeing implies adapting. PLOS ONE 2012;7(11):e50181. http://dx.doi.org/10.1371/ journal.pone.0050182.

[28] Lindner M, Maroschek M, Nethere S, Kremer A, Barbati A, Garcia-Gonzalo J, et al. Climate change impacts, adaptive capacity, and vulnerability of European forest ecosystems. For Ecol Manag 2010;259:698-709.

[29] Acosta L, Klein RJT, Reidsma P, Metzger MJ, Rounsevell MDA, Leemans R, et al. A spatially explicit scenario-driven model of adaptive capacity to global change in Europe. Glob Environ Chang 2013;23:1211-24.

[30] Törnqvist T. Skogsrikets arvingar. En sociologisk studie av skogsägarskapet inom privat, enskilt skogsbruk. Forskningsrapport 6. Uppsala: SAMU; 1995.

[31] Bieling C. Non-industrial private-forest owners: possibilities for increasing adoption of close-to-nature forest management. Eur J For Res 2004;123:293-303.

[32] Baptista FO, Santos RT. Os Proprietários Florestais - resultados de um inquérito. Celta Ed Port; 2005, ISBN 9789727741953. p. 93.

[33] Ingemarson F. Small-scale forestry in Sweden - owners' objectives, silvicultural practices and management plans. PhD diss. Uppsala: Swedish University of Agricultural Sciences; 2004. 